gitis, however, the drug was found in brain almost exclusively in animals with intensive signs of meningitis.

Ampicillin, particularly in large doses, had a distinct therapeutic effect in experimental Hæmophilus meningitis
The pathological changes in the meninges corresponded to the clinical picture. In experiments with $\beta$-streptococci and Hamophilus influenza, however, mild changes were discernible even before signs of meningitis had appeared.

\title{
H. INFLUENZÆ MENINGITIS: A CONTROLLED STUDY OF TREATMENT WITH AMPICILLIN
}

\author{
Lauri D. Thrupp,- John M. Leedom, Daniel Ivler, Paul F. Wehrle, \\ John F. Brown, Allen W. Mathies and Bernard Portnoy.
}

From the Communicable Disease Service, Los Angeles County General Hospital, and the Infectious Disease Laboratory, the Departments of Medicine and Pediatrics, University of Southern California School of Medicine.

THE case fatality rate in Hemophilus influenzue meningitis has been reduced to $5-10 \%$ by present methods of anti-bacterial and supportive therapy. As this rate is still far from optimal, the incidence of both early and late neurological sequelæ is appreciable, and the antibiotics presently employed have definite, and occasionally serious toxicity, new approaches to therapy must be evaluated.

Preliminary in vitro studies performed in our laboratory (Ivler, Thrupp, Leedom, Wehrle and Portnoy, 1963) indicated that 126 strains (118 type B) of $H$. influenzae isolated from cerebrospinal fluid (C.S.F.) were sensitive to ampicillin. Bacteriostatic and bactericidal levels did not differ significantly, and $91 \%$ were killed by $0.4 \mu \mathrm{g} . / \mathrm{ml}$. Only one had a bactericidal level as high as $1.6 \mu \mathrm{g} . / \mathrm{ml}$. In addition, sensitivities of meningococci and pneumococci to ampicillin were similar to those to penicillin G. These data, in conjunction with the apparent low toxicity of ampicillin suggested the trial of ampicillin as a single drug treatment for bacterial meningitis, in contrast to control groups treated with conventional therapy. The present report summarizes the experience to date with $H$. influenza meningitis. Eighteen of these 70 patients were included in a preliminary report (Iver et al., 1963).

\section{Materials and Methods}

(1) Selection of Patients: All patients more than two months of age with bacterial meningitis admitted to the Communicable Disease Service of the Los Angeles County General Hospital were included in the ampicillin study. Chart numbers assigned at the hospital central admitting office, and not subject to control of the ward physicians, were used to insure proper randomization. Patients with even $(2,4,6$, etc.) numbers were assigned to the ampicillin group while patients with chart numbers ending $1,3,5$, etc., were given conventional therapy. During the period considered (June, 1963 to March, 1964) a total of 72 patients were admitted with $H$. influenza meningitis. Of these, 44 with odd chart numbers were assigned to the control group, and 28 with even numbers were eligible for ampicillin therapy. The difference in the size of the two groups was unexpected, although within the limits of chance variation. Two of the 28 patients were excluded from the ampicillin group, one by error in assignment and the other because of concomitant severe facial cellulitis following a dog bite where additional therapy was indicated. These two patients were not tabulated with either group. Most of the patients had received some antibacterial therapy prior to admission, usually subtherapeutic dosages, ineffective drugs, or both. No attempt was made to evaluate this, since it was assumed to provide an equal, and probably negligible, effect in both treatment groups.

(2) Administration of antibacterial therapy: Sodium ampicillin , was reconstituted in 0.85 per cent $\mathrm{NaCl}$ and administered rapidly $(15-20$ minutes) at four hour intervals in a total daily dose of $150 \mathrm{mg}$. $/ \mathrm{kg}$. of body weight. (The first seven patients treated received $100 \mathrm{mg} . / \mathrm{kg}$. per day intra- 
venously at six hour intervals). The intravenous route was used invariably for at least the first 48 hours, while after adequate initial clinical response many patients were given the same daily dose by intramuscular injection at four hour intervals during the remainder of the period of treatment.

Chloramphenicol was given by continuous intravenous infusion in a total daily dose of $100 \mathrm{mg} . / \mathrm{kg}$. In some patients in whom the diagnosis of $\boldsymbol{H}$. influenza was not certain on admission, sulfisoxazole and penicillin $G(150 \mathrm{mg} . / \mathrm{kg}$. $/$ day of each drug) were also given until isolation and identification of the organisms were completed.

(3) Duration of therapy: Treatment was continued until the patient was afebrile for at least five days, the spinal fluid contained less than 40 cells per $\mathrm{cmm}$. with few or no polymorphonuclear leukocytes, and the C.S.F. sugar was normal.

(4) Evaluation of response to therapy: Response to therapy was evaluated by the usual clinical criteria, including duration of fever, improvement in neurological status, decrease in peripheral blood leukocyte count with a return of the differential count toward normal, and improvement in C.S.F. finding, including pressure, cell colant, percentage polymorphonuclear leukocytes and glucose and protein content.

Subdural taps were performed whenever indicated (Platou, Rinker and Derrick, 1959). In this report the outcome of therapy was evaluated according to the patient's course in the hospital and status at the time of discharge from the hospital. Untoward findings during the course of treatment in the hospital and any neurological abnormalities were recorded. "Delayed resolution clinically, but no sequelæ at discharge" is a descriptive category which included patients with one or more findings such as: (a) transient subdural effusions, (b) convulsions persisting beyond the first 24 hours in the hospital, (c) persistence of a positive C.S.F. culture the day following admission to the hospital, (d) persistence or recurrence of C.S.F. pleocytosis, (e) documented persistence of nuchal rigidity or neurological findings such as cranial nerve palsies beyond five days even though resolution had occurred by the time of discharge. An additional "slow response" category incorporated the above plus other patients with no abnormality but fever persisting beyond five days of treatment.

(5) Bacteriological methods: Isolation and identification of the organisms were accomplished by conventional methods utilizing blodd and chocolate agar, serum and thioglycollate broth and both aerobic and $\mathrm{CO}_{2}$ incubation. Quellung was done in C.S.F. if adequate numbers of organisms were present. Bactericidal levels of ampicillin and chloramphenicol were determined using serial tube dilution techniques in GC medium containing $1 \%$ supplement B. (Difco).

\section{Results}

Bacteriologic confirmation of the diagnosis of $\boldsymbol{H}$. influenza type B infection was complete in 68 of the 70 patients in the study group. Blood and C.S.F. cultures were both positive in 34 patients and organisms were cultured from the C.S.F. alone in the remaining 34. Two patients admitted with partially treated purulent meningitis had no positive cultures; they are included in this series on the basis of organisms seen on Gram's stain of the C.S.F The cultural recovery of $H$. influenza from 68/70 patients supported the assumption that antibiotic therapy given prior to admission ha $\bar{\Phi}$ little effect on the course of the illness. TQ date, 164 strains of $H$. influenza isolated from C.S.F. have been tested for in vitro sensitivity tê ampicillin. Ninety-one per cent of the straing were killed by $0.4 \mu \mathrm{g} . / \mathrm{ml}$., and only two has bactericidal end points as high as 1.6 and 3.1 $\mu \mathrm{g} . / \mathrm{ml}$. respectively.

The age and sex distribution of the patient studied is indicated in Table $I$. Two of the patients were more than 15 years of age. should be noted that 14 of 26 patients in the ampicillin group were two years of age op older, and 13 of 44 patients in the controf group were in this age group. This wa용 believed to be an unimportant difference, since the distribution of severity of illness, accord $\overrightarrow{0}$ ing to the criteria in Table II, was simila? within each age group and apparently was not related to age. The expected male predomi nance was found in both study groups.

The duration of illness prior to admissigen was similar in both groups. In Table II the patients in each group are recorded $\Phi_{t}$ severity of illness on admission. There no difference between the two groups.

The duration of fever after therapy was instituted as indicated in Table III. No signifis cant difference is apparent between the tw\& groups. Sixty-four per cent of the chloramo phenicol treated patients were afebrile by the fifth hospital day, while $72 \%$ of the ampicilling group were in this category.

The C.S.F. was re-examined within one of two days following admission in 24 ampicilling and 38 control patients. Cultures of these follow-up C.S.F. samples were positive in threes of 31 specimens from the ampicillin patientș and three of 46 samples from controls. These six positive specimens were all obtained less than 18 hours after the start of therapy; nog positive C.S.F. cultures were obtained from either treatment group later than 18 hourse after admission. The similarity of response in the two treatment groups is further emphasized in Figs. 1 and 2, in which changes in C.S.F. cell count and glucose are shown during the period of therapy. In addition to the data shown, the rate of decline in perceneo tage of polymorphonuclear cells in the C.S.F. during the period of treatment was similar in? the two groups. 
TÄBLE I

H. influenza meningitis

Age and Sex Distribution of Patients by Therapy Group

\begin{tabular}{ccccccc}
\hline $\begin{array}{c}\text { Therapy } \\
\text { Group }\end{array}$ & Sex & $<1$ yr. & 1 yr. & $2-4$ yrs. & $5-29$ yrs. & Totals \\
Control & M & 10 & 7 & 3 & 3 & 23 \\
Total & F & $\frac{9}{19}$ & $\frac{5}{12}$ & $\frac{5}{8}$ & $\frac{2}{5}$ & $\frac{21}{44}$ \\
Ampicillin & M & $\frac{7}{7}$ & $\frac{7}{3}$ & $\frac{6}{6}$ & $\frac{0}{16}$ & $\frac{1}{16}$ \\
Total & F & $\frac{2}{9}$ & $\frac{0}{3}$ & $\frac{6}{2}$ & $\frac{2}{26}$ \\
\hline
\end{tabular}

TABLE II

$H$. influenza meningitis

Clinical Status on Hospital Admission According to Treatment Group

\begin{tabular}{|c|c|c|c|c|c|}
\hline $\begin{array}{l}\text { Severity } \\
\text { Group }\end{array}$ & Findings & No. & $\begin{array}{l}\text { Control } \\
\text { (Per cent) }\end{array}$ & & $\begin{array}{l}\text { picillin } \\
\text { (Per cent) }\end{array}$ \\
\hline & \multirow{4}{*}{$\begin{array}{l}\text { Coma, shock, semicoma, } \\
\text { hypotension* } \\
\text { Convulsions without coma or } \\
\text { shock } \\
\text { Temp. > }>105^{\circ} \mathbf{R} \text {, symptoms } \\
>5 \text { days, complicating disease, } \\
\text { marked lethargy* } \\
\text { None of above }\end{array}$} & 8 & (18) & 3 & (12) \\
\hline & & 10 & (23) & 7 & (27) \\
\hline $2+$ & & 15 & (34) & 9 & (34) \\
\hline \multirow[t]{2}{*}{$1+$} & & 11 & (25) & 7 & (27) \\
\hline & Total patients & 44 & (100) & 26 & $(100)$ \\
\hline
\end{tabular}

TABLE III

H. influenzae meningitis

Duration of Fever in Hospital by Treatment Group

\begin{tabular}{|c|c|c|c|c|c|c|c|}
\hline \multirow{3}{*}{$\begin{array}{l}\text { Therapy } \\
\text { Group }\end{array}$} & \multicolumn{7}{|c|}{$\begin{array}{c}\text { Number (Per cent distribution) of Patients with Maximum } \\
\text { Temperature }>100^{\circ} \mathrm{F} \text {. }\end{array}$} \\
\hline & \multicolumn{7}{|c|}{ Days in Hospital } \\
\hline & $0-1$ & $2-3$ & $4-5$ & $6-7$ & 8-9 & $10+$ & Total \\
\hline Control & $\begin{array}{c}3 \\
(8)\end{array}$ & $\begin{array}{c}11 \\
(28)\end{array}$ & $\begin{array}{c}11 \\
(28)\end{array}$ & $\begin{array}{c}8 \\
(21)\end{array}$ & $\begin{array}{c}2 \\
(5)\end{array}$ & $\begin{array}{c}4 \\
(10)\end{array}$ & $\begin{array}{l}39 * \\
(100)\end{array}$ \\
\hline \multirow[t]{2}{*}{ Ampicillin } & 6 & 3 & 9 & 1 & 2 & 4 & $25^{* *}$ \\
\hline & 24 & (12) & (36) & (4) & (8) & (16) & $(100)$ \\
\hline Total & 9 & 14 & 20 & 9 & 4 & 8 & 64 \\
\hline
\end{tabular}


TABLE IV

$H$. influenze meningitis

Complications and Sequelæ by Type of Treatment

\begin{tabular}{|c|c|c|c|c|}
\hline \multirow[b]{2}{*}{ Death } & \multicolumn{2}{|c|}{$\begin{array}{l}\text { Control } \\
\text { No. (Per cent) }\end{array}$} & \multicolumn{2}{|c|}{$\begin{array}{l}\text { Aimpicillin } \\
\text { No. (Per cent) }\end{array}$} \\
\hline & 4 & (9) & 1 & (4) \\
\hline $\begin{array}{l}\text { Neurological Residual* } \\
\text { Severe } \\
\text { Mild or Questionable }\end{array}$ & 5 & (11) & 3 & (12) \\
\hline $\begin{array}{l}\text { Subdural Effusions } \\
\text { Required Surgery } \\
\text { Mild Neurological Residual } \\
\text { No sequelæ }\end{array}$ & 4 & (9) & 4 & (15) \\
\hline Seizures persistent** & 1 & (2) & 2 & (8) \\
\hline $\begin{array}{l}\text { Delayed resolution clinically } \ddagger \text { but } \\
\text { no sequelæ at discharge }\end{array}$ & 13 & (30) & 8 & $(31)$ \\
\hline $\begin{array}{l}\text { Temp. }>100^{\circ} \mathrm{F} \text {. for } 6 \text { days but } \\
\text { without any of the above } \\
\text { findings }\end{array}$ & 5 & (11) & 1 & (4) \\
\hline $\begin{array}{l}\text { Good response (none of above } \\
\text { findings) }\end{array}$ & 18 & $(41)$ & 13 & (54) \\
\hline
\end{tabular}

* At hospital discharge.

** Some seizures persistent $>24$ hours after admission.

$\ddagger$ Tabulation includes patients with slight subdural effusions which cleared without surgery or neurological sequelæ.

TABLE V

$H$. influenza meningitis

Status on Discharge from the Hospital

\begin{tabular}{|c|c|c|c|c|c|}
\hline $\begin{array}{l}\text { Age } \\
\text { Group }\end{array}$ & $\begin{array}{l}\text { Treatment } \\
\text { Group }\end{array}$ & $\begin{array}{l}\text { No Residual } \\
\text { Satisfactory } \\
\text { Response }\end{array}$ & $\begin{array}{l}\text { Slight or no } \\
\text { Residual with } \\
\text { Minor Subdurals } \\
\text { or Slow Response }\end{array}$ & $\begin{array}{c}\text { Serious } \\
\text { Neurologic } \\
\text { Residual } \\
\text { or Death }\end{array}$ & Total \\
\hline$<12$ mos. & $\begin{array}{l}\text { Control } \\
\text { Ampicillin }\end{array}$ & $\begin{array}{l}9 \\
0\end{array}$ & $\begin{array}{l}9 \\
6\end{array}$ & $\begin{array}{l}1 \\
3\end{array}$ & $\begin{array}{r}19 \\
9\end{array}$ \\
\hline & Total & 9 & 15 & 4 & 28 \\
\hline 12-23 mos. & $\begin{array}{l}\text { Control } \\
\text { Ampicillin }\end{array}$ & $\begin{array}{l}7 \\
2\end{array}$ & $\begin{array}{l}3 \\
1\end{array}$ & $\begin{array}{l}2 \\
0\end{array}$ & $\begin{array}{r}12 \\
3\end{array}$ \\
\hline & Total & 9 & 4 & 2 & 15 \\
\hline $2+$ yrs. & $\begin{array}{l}\text { Control } \\
\text { Ampicillin }\end{array}$ & $\begin{array}{r}6 \\
12\end{array}$ & $\begin{array}{l}5 \\
2\end{array}$ & $\begin{array}{l}2 \\
0\end{array}$ & $\begin{array}{l}13 \\
14\end{array}$ \\
\hline & Total & 18 & 7 & 2 & 27 \\
\hline All Ages & $\begin{array}{l}\text { Control } \\
\text { Ampicillin }\end{array}$ & $\begin{array}{l}22 \\
14\end{array}$ & $\begin{array}{r}17 \\
9\end{array}$ & $\begin{array}{l}5 \\
3\end{array}$ & $\begin{array}{l}44 \\
26\end{array}$ \\
\hline & Total & 36 & 26 & 8 & 70 \\
\hline
\end{tabular}


TABLE VI

$H$. influenza meningitis

Possible Reactions or Complications of Therapy

\begin{tabular}{|c|c|c|c|c|}
\hline \multirow{3}{*}{$\begin{array}{l}\text { Type of Reaction } \\
\text { Any possible reaction } \\
\text { Phlebitis } \\
\text { Skin Rash } \\
\text { Gastrointestinal } \\
\text { Miscellaneous }\end{array}$} & \multirow{2}{*}{\multicolumn{2}{|c|}{$\begin{array}{c}\text { Control } \\
\text { (44 patients) } \\
\text { No }\end{array}$}} & \multicolumn{2}{|c|}{$\underset{\text { (26 patients) }}{\text { Ampicillin }}$} \\
\hline & & & & \\
\hline & $\begin{array}{r}20 \\
9 \\
4 \\
3 \\
6\end{array}$ & $\begin{array}{r}(45) \\
(20) \\
(9) \\
(7) \\
(14)\end{array}$ & $\begin{array}{r}16 \\
10 \\
5 \\
1 \\
1\end{array}$ & $\begin{array}{r}(62) \\
(38) \\
(19) \\
(4) \\
(4)\end{array}$ \\
\hline 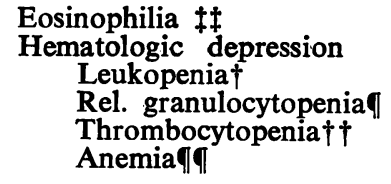 & $\begin{array}{r}3 \\
10\end{array}$ & $\begin{array}{l}(7) \\
(23)\end{array}$ & $\frac{1}{2+}$ & $\begin{array}{l}0 \\
1 \\
1 \\
1\end{array}$ \\
\hline \multicolumn{5}{|c|}{ 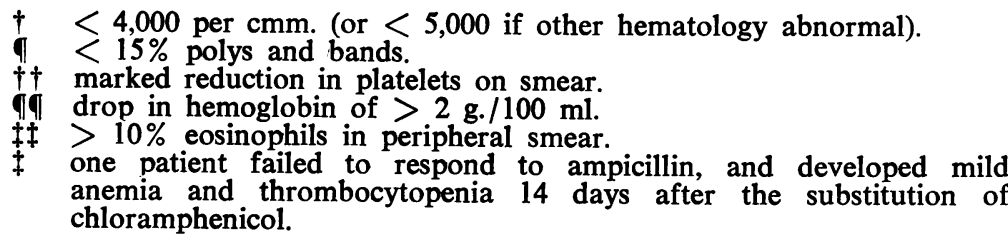 } \\
\hline
\end{tabular}

Complications seen are recorded in Table IV by type of sequelæ and method of therapy. Again, it is apparent that no significant difference is present between the two groups. A strong association was found with coma, shock and/or convulsions on admission and fatal outcome or serious neurological residual. This was the case in both therapeutic groups. None of the 42 patients admitted without the above serious clinical signs had a fatal outcome or neurological sequelæ of consequence. Among the 28 patients admitted with coma, shock or convulsions, four of 18 treated with chloramphenicol died and one had a serious residual. One of 10 in the ampicillin series died, and an additional two patients had severe residual involvement (hydrocephalus).

The status of the patients at the time of discharge by age group and type of therapeutic response is recorded in Table V. Although minor differences were noted among the various age groups, the numbers were small and of doubtful significance. In the total group, the proportion with entirely satisfactory response was 22 of 44 control patients and 14 of 26 ampicillin patients. These proportions may be regarded as nearly identical.
Possible drug reactions or complications of therapy are listed in Table VI. These findings? were not proven to be due to the specific antibiotic therapy in any instance. The high incidence of local phlebitis in both groups accompanied the frequent use of polyethylene, indwelling, venous catheters. Twelve patients with some evidence of hematologic depression are also listed in Table VI, although the findings were minimal in most. Eleven cases accompanied the administration of chloramphenicol. One three-month-old patient treated with ampicillin had a peripheral white blood cell differential count of $15 \%$ polymorphonuclears and no bands on the seventh day of therapy. This finding was of doubtful significance in view of the age of the patient, lack of accompanying anemia or leukopenia, and a reticulocyte count of $1.6 \%$. The other patient with hematologic depression included in the ampicillin group was treated initially with ampicillin with prompt sterilization of C.S.F. However, the pleocytosis failed to clear, and subdural effusions and hydrocephalus were noted. The marrow depression appeared two weeks after chloramphenicol had been subsitituted. 
H. INFLUENZAE MENINGITIS

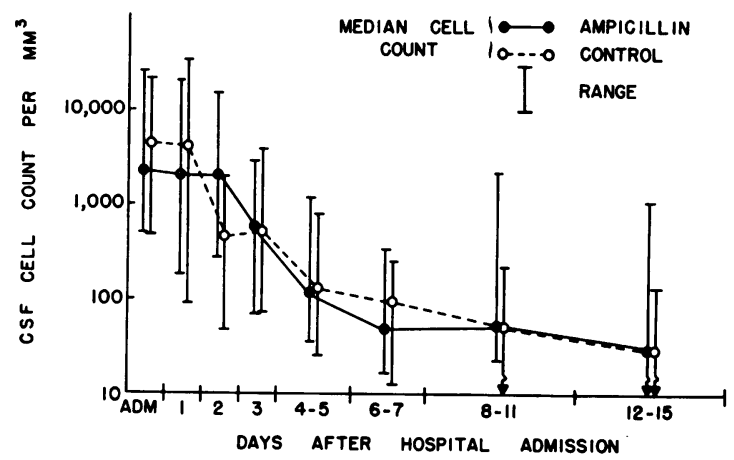

FIG. 1.-C.S.F. cell counts during the treatment period.

\section{Discussion}

The patients with $H$. influenza meningitis in this study comprised a group similar to series previously reported (Haggerty and Ziai, 1964). $90 \%$ of the patients were between two months and four years old. This age distribution followed the characteristic pattern which, as shown by Fothergill and Wright (1933), reflects inversely the age prevalence of bactericidal serum antibody. Three per cent (two cases) were young adults, a proportion similar to the $2.7 \%$ of patients more than 20 years of age recorded in Dolphin and Popham's (1951) review of 915 cases. There was the expected male predominance.

Analysis of the results of therapy with ampicillin and chloramphenicol in these two comparable groups of patients failed to elicit any clear-cut differences. General clinical criteria such as mortality, neurological sequelæ, duration of fever, subdural effusions, sterilization of the C.S.F. rates of reduction in the number of cells, per cent polys and protein content in C.S.F. and rise in C.S.F. sugar, were similar in both groups. The C.S.F. cell counts and sugar levels showed no differences on the first and the third days after admission, or afterwards. Among small numbers of observations on the second day, the larger variation in values for the ampicillin patients resulted in differences in distributions of values about the medians for that single day of bordering significance (Figs. 1 and 2). However, in view of the data for the days prior to, and following, this second day of treatment, it is doubtful that these differences were meaningful.

Although all nine ampicillin patients less than one year of age manifested at least some
H. INFLUENZAE MENINGITIS

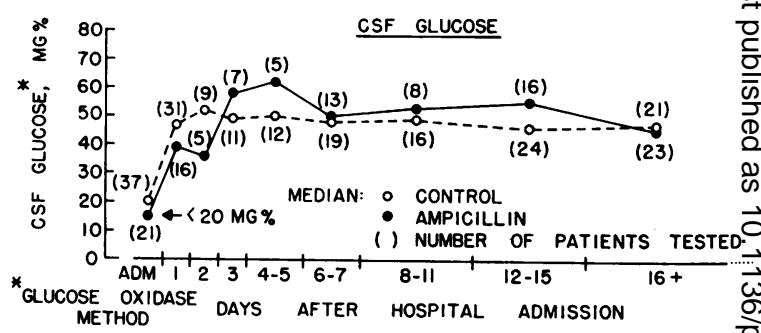

Fig. 2.-C.S.F. glucose levels during the treatment period.

deficiency in response to therapy, nine of 19 controls in this age group had satisfactory responses (Table V). A trend toward fewef unsatisfactory responses with ampicillin that chloramphenicol was observed in patients two or more years of age. As stated previously 8 neither therapeutic group was weighted witlo disproportionate numbers of severely ill moderately ill patients at any age. Disregabil ing age, the proportion of satisfactory reseo ponses in both therapeutic groups was almōं identical. The apparent minor differences Fin response to ampicillin and chloramphenicol bys age group would probably disappear if more patients were tested. Consideration of these्य data emhasizes the difficulty of being certaing that every important variable is known in any clinical study.

The one patient in the ampicillin group whos died and the two who survived with majo residua were all severely ill on admission: Nevertheless the clinical findings in these two survivors were of interest in that C.S.F. pleocytosis with polymorphonuclear predominance persisted in one, and both developed subdura $B$ effusions and hydrocephalus eventually requir ing neurosurgical correction. None of the patients in the control group required neuro- $\rightarrow$ surgery, although it should be noted that fouro deaths occurred in this group.

Several studies have demonstrated the in vitro effectiveness of ampicillin againsto $H$. influenzae (Rolinson and Stevens, $1961 ;$ స Klein and Finland, 1963) including type BO strains isolated from C.S.F. in our hospitalo (Ivler et al., 1963). Although ampicillin吕 displayed significantly more activity in vitro? than penicillin $G$ against C.S.F. $H$. Influenza 
isolates, the differences were small and of questionable clinical significance (Ivler et al., 1963). Nevertheless, the overall response of patients with $H$. influenzo meningitis treated with ampicillin was comparable to the results observed with chloramphenicol. These favourable results with ampicillin stand in contrast to the reported experience with penicillin $G$ even when patients treated with the latter drug had meningitis due to $H$. influenzae strains sensitive to penicillin $\mathrm{G}$, and C.S.F. penicillin $G$ levels were maintained by intrathecal therapy (Drysdale, McIntosh and Brodie, 1946; Zinnemann, 1946; Thomson, Bruce and Green, 1947). Perhaps qualitative differences in the activity of ampicillin and penicillin $\mathrm{G}$ against $H$. influenza account for the more effective results with ampicillin.

Ampicillin levels in the C.S.F. samples studied to date have been variable, ranging from 0.1 to $1.0 \mu \mathrm{g}$. $/ \mathrm{ml}$. with average C.S.F.to-serum ratios of 20 to $30 \%$. These C.S.F. levels seem rather low in view of the overall satisfactory clinical response to ampicillin. Indeed, C.S.F. levels of 0.1 to $1.0 \mu \mathrm{g} . / \mathrm{ml}$. barely approximate the in vitro minimum bactericidal concentrations (Ivler et al., 1963) and clinical responses have not correlated well with C.S.F. levels. For example, a C.S.F. sample from an eight month old patient who developed subdural effusion and hydrocephalus contained more than $7.0 \mu \mathrm{g} . / \mathrm{ml}$. of ampicillin, one of the highest levels found in any patient.

The peripheral blood differential count of $15 \%$ neutrophils noted in a three month old in the ampicillin group on the seventh day of therapy could not be considered definitely abnormal. The anemias, leukopenias, granulocytopenias and thrombocytopenias observed in the control patients on chloramphenicol therapy all subsided after the drug was discontinued. One control patient who developed anemia, thrombocytopenia and leukopenia, concurrently developed staphylococcal pneumonia and extensive phlebitis and cellulitis at the site of an intravenous polyetheylene catheter. However, as the patient's differential count remained normal, and the lowest total white blood cell count recorded was 3,100 per $\mathrm{cmm}$. the superinfection was not necessarily related to the mild leukopenia.

\section{Summary}

Overall results of treatment of $H$. influenzae meningitis with ampicillin or chloramphenicol appeared comparable, but no definite advantages were demonstrated in the use of ampicillin other than the freedom from hematologic depression. While one death occurred among the ampicillin group and two additional patients required neurosurgical procedures for correction of hydrocephalus, four control patients died and one had severe neurological residual. Further study, perhaps with higher dosage, is indicated.

This study was supported in part by the Hastings Foundation, and a grant from Bristol Laboratories, Syracuse, New York, U.S.A.

John M. Leedom is an Epidemic Intelligence Service Officer, Epidemiology Branch, Communicable Disease Center, U.S. Public Health Service.

Dr. Bernard Hanes provided statistical advice.

We should like to thank Robert A. Murray for technical assistance and Drs. A. Burckin, A. Christiansen, P. Robbie and V. Spilotro for assistance in reviewing clinical data and the house staff of the Communicable Disease Service, Los Angeles County General Hospital for their co-operation and excellent care of the patients.

The diagnostic bacteriology was directed by $\frac{\mathbb{1}}{3}$ Margaret Parrish and Patricia Hagen, in the Communicable Disease Section of the Microbiology $\delta$ Laboratories, Dr. Robert Clelland, Director, Los Angeles County General Hospital.

Ampicillin assays were performed by Bristol Laboratories, Syracuse, New York.

\section{References}

Dolphin, A., and Popham, R. D. (1951): Lancet, ii, 472.

Drysdale, C., McIntosh, D., and Brodie, J. (1946): Brit. med. J., ii, 223.

FOTHERGILL, L." D., and WRIGHT, J. (1933): J. Immunol., 24, 273.

HAGGERTY, R. J., and ZIAI, M. (1964): Advanc. Pediat., 13, 129.

IVler, D., ThrupP, L. D., Leedom, J. M., WehrLe, P. F., and PoRTNOY, B. (1963): Antimicrobial Agents and Chemotherapy-1963. p. 335, American Society of Micrnbiology.

Klein, J. O., and Finland, M. (1963): Amer. J. med. Sci., 245, 544.

Platou, R. V., Rinker, A., and Derrick, J. (1959): Pediatrics, 23, 962.

Rolinson, G., and Stevens, S. (1961): Brit. med. J., ii, 191.

Thomson, J., Bruce, L., and Green, M. (1947): Brit. med. J., ii, 414.

ZiNNEMANN, K. (1946): Brit. med. J., ii, 931. 